\author{
ZBIGNIEW ZIOt0 \\ Podkarpacka Szkoła Wyższa im. bł. ks. W. Findysza w Jaśle, Polska - Podkarpacka Higher Education School \\ in Jasto, Poland \\ TOMASZ RACHWAt \\ Uniwersytet Pedagogiczny w Krakowie, Polska - Pedagogical University of Cracow, Poland
}

\title{
Zarys uwarunkowań dalszego rozwoju przedsiębiorczości w układach przestrzennych
}

\section{Outline of Conditions for Further Development of Entrepreneurship in Spatial Systems}

\begin{abstract}
Streszczenie: Procesy rozwoju przedsiębiorczości w układach przestrzennych zachodzą pod wpływem wielu różnorodnych czynników, wynikających za zmieniających się uwarunkowań wewnętrznych i zewnętrznych. W artykule podjęto więc próbę identyfikacji uwarunkowań wpływających na możliwości dalszego rozwoju działalności gospodarczej, traktowanej jako podstawowy przejaw przedsiębiorczości. Do głównych uwarunkowań zaliczono czynniki związane z ogólnymi procesami rozwoju społecznego, gospodarczego i kulturowego, postępującą globalizacją działalności gospodarczej, kształtowaniem społeczeństwa informacyjnego, poziomem edukacji i rozwojem działalności badawczo-rozwojowej, jakością kadr i elit władzy oraz wdrażaniem zasad etycznych do biznesu i życia społecznego. Wskazano również na potencjalne czynniki hamujące rozwój, wynikające $z$ negatywnych cech osobowości elit władzy i przedsiębiorców. Identyfikacja tych uwarunkowań procesu dalszego rozwoju powinna służyć doskonaleniu treści i metod edukacji w zakresie przedsiębiorczości oraz analizom kształtowania przedsiębiorczości w układach lokalnych i regionalnych. Wyznacza ona także kierunki dalszych badań, które powinny zmierzać do coraz precyzyjniejszego poznania procesu kształtowania przedsiębiorczości w drodze zarówno doskonalenia ujęć teoretycznych, jak i ich weryfikacji w badaniach empirycznych z uwzględnieniem ich możliwości aplikacyjnych.
\end{abstract}

\begin{abstract}
The processes of entrepreneurship development in spatial systems take place under the influence of many different factors resulting from the changing of internal and external conditions. Thus, the article attempts to identify conditions affecting further possibilities of business development, treated as a basic expression of entrepreneurship. The main determinants include factors related to general processes of social, economic and cultural development, progressive globalisation of economic activity, development of the information society, level of education and development of research and development activities, quality of personnel and power elites and implementation of ethical principles to business and social life. The authors also pointed to potential factors hampering the development resulting from the negative personality traits of the power elite and entrepreneurs. Identification of these conditions of the process of further development should be used to improve the content and methods of entrepreneurship education and to analyse the development of entrepreneurship in local and regional systems. It also sets the directions for further research, which should aim at more and more accurate understand-
\end{abstract}


ing of the process of entrepreneurship development through the improvement of both theoretical approaches and their verification in empirical research, taking into account their application possibilities.

Słowa kluczowe: edukacja; rozwój przedsiębiorczości; startup; układ przestrzenny; uwarunkowania rozwoju

Key words: conditions of development; education; entrepreneurship development; spatial system; startup

Otrzymano: 20 lutego 2019

Received: 20 February 2019

Zaakceptowano: 27 marca 2019

Accepted: 27 March 2019

Sugerowana cytacja/Suggested citation:

Zioło, Z., Rachwał, T. (2019). Zarys uwarunkowań dalszego rozwoju przedsiębiorczości w układach przestrzennych. Przedsiębiorczość - Edukacja [Entrepreneurship - Education], 15(1), 7-18. doi: $10.24917 / 20833296.151 .1$

\section{Wstęp}

Procesy przemian gospodarczych, społecznych i kulturowych dokonują się pod wpływem wielu różnorodnych czynników, wynikających za zmieniających się uwarunkowań wewnętrznych i zewnętrznych oraz stopnia wykorzystania zasobów wiedzy i umiejętności przez elity zarządzające. W procesie zarządzania elity te mogą wpływać na wzrost znaczenia potencjału ekonomicznego poszczególnych firm i instytucji, ich stagnację, recesję lub zanik, ale także mogą przyczyniać się do pojawiania się nowych elementów, które będą przejmować funkcję dynamizujące i zmieniające już wcześniej ukształtowane układy przestrzenno-strukturalne. Nowe podmioty gospodarcze pojawiają się najczęściej pod wpływem postępu cywilizacyjnego i w znacznym stopniu wpływają na wyznaczanie dalszych kierunków rozwoju społecznego, gospodarczego i kulturowego (Zioło, 2005, 2006, 2007, 2008).

Dotychczasowe osiągnięcia badawcze w zakresie edukacji i rozwoju przedsiębiorczości oraz wypracowane nowe koncepcje analityczne pozwalają na coraz precyzyjniejsze poznawanie procesów przemian i funkcji przedsiębiorczości w rozwoju układów przestrzennych. Umożliwiają one podejmowanie prób cząstkowych syntez dotychczasowych wyników prac badawczych oraz określania wpływu zmian uwarunkowań na dalszy rozwój przedsiębiorczości w układach przestrzennych (Rachwał, 2018; Zioło, Rachwał, 2005, 2009, 2010, 2011, 2013, 2016, 2017). Przyjmujemy, że w następnych latach rozwój przedsiębiorczości dokonywać się będzie w nawiązaniu do zmieniających się uwarunkowań wywołanych przez intensywny postęp cywilizacyjny, procesy globalizacji oraz wkraczanie w fazę społeczeństwa informacyjnego, w której podstawową bazą ekonomiczną staje się nauka, a gospodarka opiera się na wiedzy. Zróżnicowane uwarunkowania układów przestrzennych powodują różny stopień ich atrakcyjności dla dynamizowania procesów rozwoju przedsiębiorczości. W konsekwencji wpływają one na przestrzenną polaryzację rozwoju gospodarczego, społecznego i kulturowego oraz różnicowanie poziomu i jakości życia. W niniejszych rozważaniach podejmujemy próbę identyfikacji uwarunkowań wpływających na dalsze możliwości rozwoju działalności gospodarczej, traktowanej jako 
podstawowy przejaw przedsiębiorczości. Powinna ona służyć doskonaleniu treści i metod edukacji w zakresie przedsiębiorczości oraz analizom kształtowania przedsiębiorczości w układach lokalnych i regionalnych.

\section{Przesłanki dalszego rozwoju przedsiębiorczości}

Na kształtowanie się procesów rozwoju znaczący wpływ wywiera struktura przestrzeni geograficznej. Wykazuje ona duże zróżnicowanie w różnej skali układach przestrzennych, od skali światowej i kontynentalnej, przez skalę krajową, regionalną po skalę lokalną. Układy te $\mathrm{z}$ reguły odznaczają się różnym poziomem rozwoju społecznego, gospodarczego i kulturowego, stwarzają odmienne uwarunkowania oraz możliwości rozwoju przedsiębiorczości w układach sektorowych (Kuciński, 2007; Kudełko, 2007; Kudełko, 2013; Klasik, Kuźnik, 2018; Rachwał, 2018; Zioło, 2005, 2008). W zależności od potencjału przedsiębiorstw (małe i średnie - duże) oddziałują one na nie z różnym nasileniem.

Każdy podmiot gospodarczy generujący procesy rozwoju układów przestrzennych stanowi określoną jednostkę, w której przedsiębiorca (właściciel) czy zarząd podejmuje samodzielne decyzje, kierując się własnym interesem z uwzględnieniem możliwości występowania ryzyka i pojawienia się negatywnych skutków podejmowanych decyzji. Dlatego należy przyjąć, że podstawową rolę w procesach rozwoju społecznego, gospodarczego i kulturowego odgrywają przedsiębiorcy, którzy przez podejmowane decyzje wpływają na rozmiary potencjału i kierunki działalności produkcyjnej oraz usługowej, określają zmienność wielkości i strukturę asortymentów produkcji, usług i aktywizują rynki pracy, przy założeniu, że podstawowym celem ich działalności jest osiąganie jak najkorzystniejszych efektów ekonomicznych, głównie przez maksymalizację zysków. W zależności od rozmiarów i efektywności ich działalności gospodarczej zasilają oni z kolei fundusze władz centralnych, samorządowych i in. (Szlachta, 2018).

W procesie działalności firm ważnym problemem jest określanie nie tylko bieżącej taktyki postępowania, ale także długookresowej strategii rozwoju przedsiębiorstwa. Są to bardzo trudne i złożone zadania, które rozwiązuje się, uwzględniając jakość i wielkość potencjału ekonomicznego, technicznego i funkcji firmy w gospodarce: lokalnej, regionalnej, krajowej czy międzynarodowej; możliwości utrzymania i pogłębiania chłonności istniejących rynków oraz możliwości opanowywania nowych rynków, a także zmieniających się uwarunkowań gospodarczych, społecznych i politycznych występujących w różnej skali układach przestrzennych, zwłaszcza w skali krajowej, europejskiej i światowej ${ }^{1}$.

${ }^{1} \mathrm{Na}$ uwarunkowania światowe w zasadniczym stopniu wpływają zmiany krajów w światowym potencjale gospodarczym. W 1995 r. dominującą pozycję w światowej gospodarce zajmowały Stany Zjednoczone i Japonia, obejmujące łącznie $42,8 \%$ światowego PKB. W następnych latach udział Japonii zmniejszył się z 14,0\% do 4,6\% w 2016 r., udział Stanów Zjednoczonych utrzymywał się na zbliżonym poziomie i wynosił odpowiednio $24,9 \%$ i 24,7\%, natomiast znacznie wzrósł udział Chin - z 2,4\% do 14,8\%. W konsekwencji miejsce Japonii zajęły Chiny, które łącznie ze Stanami Zjednoczonymi obejmują 39,5\% światowego PKB. Wykształciła się w tym czasie nowa struktura gospodarcza - Unia Europejska, która w 2016 r. obejmowała 24,0\% światowego PKB. Należy wnosić, że w następnych latach rozwój gospodarki poszczególnych krajów zależał będzie od dynamiki rozwoju i wzajemnych stosunków polityczno-gospodarczych tych trzech światowych biegunów wzrostu, które obecnie łącznie obejmują 63,5\% światowego PKB. 
Zachowanie podmiotu gospodarczego wynika nie tylko z pojawiania się i intensyfikowania czynników rozwojowych, ale także z występowania ograniczeń realnych i regulacyjnych. Ograniczenia realne tworzą: warunki przyrodnicze, zasoby finansowe, kapitałowe i kadrowe, wymagania technologiczne oraz rozmiary chłonności rynku, gospodarstw domowych i instytucji, a także możliwości nawiązywania powiązań kooperacyjnych z innymi podmiotami gospodarczymi i instytucjami. Ograniczenia regulacyjne tworzą wdrażane na różnych poziomach władzy instrumenty bezpośredniego (głównie prawne) i pośredniego oddziaływania. W konsekwencji rozwój przedsiębiorczości oraz działalności podmiotów gospodarczych i instytucji dokonuje się zwykle w takich układach przestrzennych, w których występują możliwości osiągania maksymalnych efektów ekonomicznych.

\section{Uwarunkowania dalszego rozwoju przedsiębiorczości jako podstawy budowania strategii rozwoju działalności gospodarczej}

Dla podejmowania prób określania możliwości dalszego rozwoju przedsiębiorczości niezmiernie ważnym zadaniem jest poznanie stopnia złożoności i jakości zmieniających się uwarunkowań oraz możliwości sterowania nimi na rzecz efektywnego rozwoju działalności gospodarczej (tabela 1). Zdajemy sobie sprawę, że w dalszym racjonalnym rozwoju przedsiębiorczości w układach przestrzennych bardzo ważnymi czynnikami są zasoby intelektualne społeczeństwa, które dają możliwość kształtowania kapitału ludzkiego i społecznego, oraz nasilający się proces rozwoju cywilizacyjnego. Powinny one w podstawowym stopniu służyć realizacji podstawowego celu rozwoju, jakim jest podnoszenie poziomu i jakości życia.

Generalnie w układach przestrzennych na zmienność przyszłych uwarunkowań rozwoju przedsiębiorczości w podstawowym stopniu wpływać będą procesy rozwoju cywilizacyjnego oraz jakość kadr zarządzających, które będą umiały wykorzystać intensyfikujące się procesy globalizacji, w warunkach rosnącej konkurencyjności dla pobudzania rozwoju układów przestrzennych. Znaczącą rolę odgrywać będzie postęp naukowy, techniczny, społeczny, gospodarczy i kulturowy, który zmierza w kierunku informacyjnej fazy rozwoju. Duże znaczenie w tych działaniach powinny mieć jakość przyjmowanych i wdrażanych postaw etycznych oraz norm moralnych, które stanowić będą układ odniesienia dla procesów ekonomicznych. Ich rola jest szczególnie duża przy podziale społecznym wypracowanych efektów ekonomicznych, które wywierają podstawowy wpływ na wyrównywanie poziomu i jakości życia oraz osłabianie procesów polaryzacji zarówno w układach przestrzennych, jak i układach struktur społecznych ${ }^{2}$. Na dalszy proces

\footnotetext{
${ }^{2}$ Przejawem narastających dysproporcji w procesie rozwoju gospodarczego jest bardzo duże przestrzenne zróżnicowanie poziomu i jakości życia. Sytuacja ta wynika z nieszanowania zasad etycznych w biznesie. W wyniku ciągłego wyzysku i braku chęci podzielenia się efektami ekonomicznymi przez zarządy światowych korporacji, kraje Afryki i Ameryki Południowej o największych zasobach surowcowych znajdują się równocześnie na najniższym poziomie rozwoju. Postępujący proces polaryzacji wygenerował współcześnie negatywne niekontrolowane zjawisko migracji ludności z obszarów o niższym poziomie rozwoju na obszary o wysokim poziomie rozwoju. Można wnosić, że liczne grupy ludności napływowej stopniowo będą wpływać na zmiany w rozwoju cywilizacyjnym krajów rozwiniętych, wprowadzając swoje zasady ukształtowane w warunkach niższego poziomu rozwoju gospodarczego i społecznego oraz zgodne z ich kulturą duchową. Wynikać to będzie z nieprzygotowania napływającej ludności do integracji społecznej i problemu braku umiejętności wykorzystania europejskich wzorców zachowań dla podnoszenia jakości i poziomu własnego życia.
} 
Tabela 1. Uwarunkowania dalszego rozwoju przedsiębiorczości

\begin{tabular}{|c|c|c|c|}
\hline \multirow{6}{*}{\multicolumn{2}{|c|}{\begin{tabular}{|l|} 
\\
Generalne uwarunkowania \\
$\begin{array}{l}\text { wynikające z procesów rozwoju } \\
\text { społecznego, gospodarczego, } \\
\text { kulturowego oraz jakości kadr }\end{array}$
\end{tabular}}} & $\begin{array}{l}\text { Intensyfikacja procesów } \\
\text { globalizacji }\end{array}$ & \multirow{5}{*}{$\begin{array}{l}\text { nasilanie się procesu polaryzacji } \\
\text { lub dążenia do wyrównywania } \\
\text { dysproporcji rozwojowych } \\
\text { układów przestrzennych }\end{array}$} \\
\hline & & Wzrost konkurencyjności & \\
\hline & & $\begin{array}{l}\text { Wzrost postępu naukowo- } \\
\text { technicznego }\end{array}$ & \\
\hline & & $\begin{array}{l}\text { Jakość przyjmowanych } \\
\text { i wdrażanych postaw } \\
\text { etycznych i norm moralnych }\end{array}$ & \\
\hline & & $\begin{array}{l}\text { Postęp cyfryzacji } \\
\text { w zarządzaniu: gospodarką, } \\
\text { produkcją, usługami, } \\
\text { edukacją, kulturą, } \\
\text { gospodarstwami domowymi }\end{array}$ & \\
\hline & & $\begin{array}{l}\text { Jakość przywódców } \\
\text { światowej, kontynentalnej, } \\
\text { krajowej, regionalnej } \\
\text { i lokalnej sceny politycznej } \\
\text { (zasoby intelektualne, } \\
\text { umiejętności zarządzania) }\end{array}$ & $\begin{array}{l}\text { wdrażanie nowych idei } \\
\text { związanych z postępem } \\
\text { cywilizacyjnym, wzrost } \\
\text { lub ograniczanie } \\
\text { zaufania w stosunkach } \\
\text { międzynarodowych, } \\
\text { wykorzystanie sytuacji } \\
\text { w światowych biegunach } \\
\text { wzrostu, zdolność ograniczania } \\
\text { napięć militarnych } \\
\end{array}$ \\
\hline \multirow{10}{*}{$\begin{array}{l}\text { Uwarunkowania } \\
\text { otoczenia }\end{array}$} & \multirow{3}{*}{ Rynki } & stagnujące & \multirow{2}{*}{ na istniejące produkty i usługi } \\
\hline & & rozwijające się & \\
\hline & & $\begin{array}{l}\text { pojawianie się nowych } \\
\text { rynków }\end{array}$ & na nowe produkty \\
\hline & \multirow{3}{*}{ Finansowe } & $\begin{array}{l}\text { jakość instrumentów } \\
\text { fiskalnych }\end{array}$ & \multirow{2}{*}{$\begin{array}{l}\text { rozwój i pobudzanie } \\
\text { działalności gospodarczej }\end{array}$} \\
\hline & & $\begin{array}{l}\text { dostępność do źródeł } \\
\text { finansowania }\end{array}$ & \\
\hline & & $\begin{array}{l}\text { dynamika zasobów } \\
\text { finansowych gospodarstw } \\
\text { domowych, podmiotów } \\
\text { gospodarczych i instytucji }\end{array}$ & $\begin{array}{l}\text { pobudzające lub ograniczające } \\
\text { wielkość popytu }\end{array}$ \\
\hline & \multirow{4}{*}{\begin{tabular}{|l|} 
Jakość elit \\
i stosunków \\
politycznych \\
między \\
krajami
\end{tabular}} & stabilne & \multirow{4}{*}{$\begin{array}{l}\text { stwarzanie określonych } \\
\text { możliwości dalszej lub nowej } \\
\text { współpracy gospodarczej, } \\
\text { społecznej, kulturowej, lub jej } \\
\text { ograniczanie }\end{array}$} \\
\hline & & bardziej korzystne & \\
\hline & & oziębiające się & \\
\hline & & wrogie & \\
\hline \multirow{10}{*}{$\begin{array}{l}\text { Nasilenie } \\
\text { tempa rozwoju } \\
\text { cywilizacyjnego } \\
\text { w drodze }\end{array}$} & \multirow{3}{*}{\multicolumn{2}{|c|}{$\begin{array}{l}\text { Postępującej globalizacji działalności, przy } \\
\text { zachowaniu własnej tradycji: }\end{array}$}} & gospodarczej \\
\hline & & & \begin{tabular}{|l|} 
społecznej \\
\end{tabular} \\
\hline & & & kulturowej \\
\hline & \multirow{4}{*}{\multicolumn{2}{|c|}{$\begin{array}{l}\text { Kształtowania społeczeństwa } \\
\text { informacyjnego, wkraczanie cyfryzacji do: }\end{array}$}} & edukacji \\
\hline & & & \begin{tabular}{|l} 
działalności produkcyjnej \\
\end{tabular} \\
\hline & & & \begin{tabular}{|l} 
działalności usługowej \\
\end{tabular} \\
\hline & & & gospodarstw domowych \\
\hline & \multirow{3}{*}{\multicolumn{2}{|c|}{$\begin{array}{l}\text { Rozwoju edukacji w zakresie nauk } \\
\text { humanistycznych, społecznych (w tym } \\
\text { ekonomicznych), ścisłych i technicznych, } \\
\text { na poziomie: }\end{array}$}} & zawodowym \\
\hline & & & średnim \\
\hline & & & akademickim \\
\hline
\end{tabular}




\begin{tabular}{|c|c|c|c|}
\hline \multirow{11}{*}{$\begin{array}{l}\text { Uwarunkowania } \\
\text { wewnętrzne } \\
\text { funkcjonowania } \\
\text { i rozwoju: } \\
\text { przesiębiorstw, } \\
\text { władzy } \\
\text { samorządowej } \\
\text { i organizacji } \\
\text { jednostek } \\
\text { samorządu } \\
\text { terytorialnego } \\
\text { w układach } \\
\text { przestrzennych }\end{array}$} & \multicolumn{3}{|c|}{$\begin{array}{l}\text { Podnoszenie jakości elit władzy samorządowej, instytucji i organizacji } \\
\text { pozarządowych }\end{array}$} \\
\hline & \multicolumn{2}{|c|}{$\begin{array}{l}\text { Działania edukacyjne (kształcenie, } \\
\text { dokształcanie, doskonalenie zawodowe) }\end{array}$} & $\begin{array}{l}\text { przekaz zasobów wiedzy, } \\
\text { umiejętności samokształcenia, } \\
\text { wzorce osobowe i zachowań } \\
\text { ludzi sukcesu (naukowego, } \\
\text { technicznego, ekonomicznego, } \\
\text { kulturowego) }\end{array}$ \\
\hline & \multirow{3}{*}{\multicolumn{2}{|c|}{ Zwiększanie w społeczeństwie zasobów: }} & intelektualnych \\
\hline & & & ludzkich \\
\hline & & & społecznych \\
\hline & \multirow{3}{*}{$\begin{array}{l}\text { Dbałość } \\
\text { o rozwój } \\
\text { działalności } \\
\text { badawczo- } \\
\text {-rozwojowej }\end{array}$} & \multicolumn{2}{|c|}{ wybór kierunków prac badawczych, rozwój specjalności } \\
\hline & & \multicolumn{2}{|c|}{$\begin{array}{l}\text { możliwości transferu wiedzy (technicznej, przyrodniczej, } \\
\text { medycznej, ekonomicznej, humanistycznej) }\end{array}$} \\
\hline & & \multicolumn{2}{|c|}{$\begin{array}{l}\text { przepływ nowoczesnych rozwiązań technologicznych, } \\
\text { technicznych, organizacyjnych, kapitału i finansów }\end{array}$} \\
\hline & \multirow{3}{*}{ Społeczne } & \multicolumn{2}{|c|}{$\begin{array}{l}\text { przyjmowanie lub odrzucanie pojawiających się } \\
\text { wzorców osobowościowych, kulturowych i kształtowanie } \\
\text { indywidualnych postaw ludzkich i społecznych }\end{array}$} \\
\hline & & \multicolumn{2}{|c|}{ wdrażanie zasad etyki do biznesu i życia społecznego } \\
\hline & & \multicolumn{2}{|c|}{$\begin{array}{l}\text { rozwijanie aspiracji jednostek ludzkich, społeczeństwa } \\
\text { (grup społecznych, społeczności układów przestrzennych) }\end{array}$} \\
\hline \multirow{4}{*}{\multicolumn{3}{|c|}{$\begin{array}{l}\text { Możliwości zakłócania procesów rozwoju i zmian uwarunkowań } \\
\text { rozwoju społecznego, gospodarczego, kulturowego i stosunków } \\
\text { politycznych w skali światowej, kontynentalnej, krajowej }\end{array}$}} & $\begin{array}{l}\text { zmiana kierunków } \\
\text { inwestowania, ograniczanie } \\
\text { funkcjonowania rynku, wyścig } \\
\text { zbrojeń }\end{array}$ \\
\hline & & & $\begin{array}{l}\text { konflikty militarne (światowe, } \\
\text { krajowe, regionalne) }\end{array}$ \\
\hline & & & $\begin{array}{l}\text { wzrost żywiołowych migracji, } \\
\text { niezadowolenia społecznego }\end{array}$ \\
\hline & & & $\begin{array}{l}\text { wzrost patologii współżycia } \\
\text { społecznego i indywidualnego }\end{array}$ \\
\hline
\end{tabular}

Źródło: opracowanie własne

rozwijania przedsiębiorczości znaczący wpływ będą wywierać nasilający się postęp cyfryzacji i wdrażanie sztucznej inteligencji we wszystkich dziedzinach życia gospodarczego, społecznego i kulturowego. Dlatego koniecznym warunkiem w tym zakresie jest dbałość o systematyczne podnoszenie poziomu i zmian treści edukacji na wszystkich szczeblach kształcenia, dokształcania i doskonalenia zawodowego. Zakładamy, że postępująca cyfryzacja wpływać będzie na podnoszenie efektywności i szybsze tempo rozwoju gospodarczego. Zmniejszać się może znaczenie dotychczasowych czynników rozwoju, które stanowią inwestycje zagraniczne, środki przekazywane z Unii Europejskiej oraz stosunkowo niskie koszty pracy.

Zmiana uwarunkowań i kierunków rozwoju gospodarczego, społecznego i kulturowego zależeć będzie przede wszystkim od jakości elit i wyłanianych z nich przywódców. Przywódcy ci w wyniku demokratycznych wyborów wpływać będą na kierunki rozwoju świata, grup państw, poszczególnych krajów, a także regionów i układów lokalnych. W zależności od celów, wiedzy i umiejętności stwarzać będą także odpowiednie warunki dla 
rozwoju przedsiębiorczości ${ }^{3}$. Podstawowe znaczenie w tym zakresie ma stopień wzajemnego zaufania oraz ograniczenie potencjalnych napięć militarnych (Skrzypczak, 2018).

Na rozwój przyszłej działalności gospodarczej, podobnie jak na rozwój działalności obecnej, w zasadniczym stopniu wpływać będzie zachowanie rynków. Mogą one stwarzać możliwości zbytu dotychczas oferowanych produktów, zwiększać lub zmniejszać zapotrzebowanie na nie oraz stwarzać zapotrzebowanie na nowe produkty i usługi. Stąd dla zarządzania ważne jest określenie, jak w zmieniającej się sytuacji zachowają się rynki i jakie będzie zapotrzebowanie na określone produkty. W rozwijaniu działalności gospodarczej ważną rolę odgrywa dostęp do źródeł finansowania, które w podstawowym stopniu będą gwarantować działalność inwestycyjną i modernizacyjną środków produkcji oraz możliwości rozwoju działalności usługowej. Duże znaczenie w tym zakresie ma jakość elit, które przez wzajemne relacje mogą stwarzać różnorodne możliwości współpracy i dostęp do rynków.

Równie istotne jest kształtowanie społeczeństwa informacyjnego, które rozumieć będzie przyszłe kierunki przemian oraz zdobędzie umiejętności wykorzystania nowych urządzeń nie tylko w poszczególnych sektorach gospodarki i układach przestrzennych, ale także w gospodarstwach domowych. W podstawowym stopniu zdecydują o tym zarówno kierunki rozwoju edukacji ekonomicznej i technicznej, jak i humanistycznej, na wszystkich poziomach kształcenia.

W kształtowaniu korzystnych uwarunkowań dla dalszego rozwoju przedsiębiorczości znaczącą rolę odgrywa sytuacja wewnętrzna danego układu przestrzennego, zwłaszcza krajowego, regionalnego i lokalnego. Kształtuje się ona pod wpływem jakości zasobów intelektualnych społeczeństwa, jakości wykreowanych elit oraz jakości wybieranych przedstawicieli władzy państwowej, samorządowej, instytucji pozarządowych i in. Korzystne uwarunkowania dla przyszłego rozwoju przedsiębiorczości stwarza dbanie o podnoszenie poziomu zasobów wiedzy i umiejętności elit władzy. Funkcję tę mogą spełniać działania wpływające na podnoszenie poziomu edukacyjnego społeczeństwa oraz osób odpowiedzialnych za rozwój, wdrażanie nowych osiągnięć i kształtowanie racjonalnych postaw społecznych. Duże znaczenie w tym zakresie mają prezentowane wzorce osobowe ludzi sukcesu ekonomicznego, społecznego, naukowego, kulturowego i in. O korzystnych działaniach może świadczyć dbałość społeczeństwa o rozwój talentów, które w podstawowym stopniu przyczyniają się do: wyznaczania nowoczesnych kierunków przemian, wdrażania i rozwijania postępu technologicznego i technicznego, wprowadzania nowych metod organizacji i zarządzania gospodarką, kreowania pozytywnych przemian społecznych, podnoszenia poziomu i jakości kapitału społecznego, co w istotnym stopniu przyczyniać się będzie do tworzenia nowoczesnego społeczeństwa i państwa ${ }^{4}$ Oznacza to, że o postępie

\footnotetext{
${ }^{3}$ Według szacunków „Forbesa”, łączny majątek wybranych członków gabinetu prezydenta Trumpa wynosi 4,5 mld dol., w tym wartość majątku sekretarza ds. handlu wynosi 2,5 mld dol., sekretarza ds. edukacji 1,25 mld dol., sekretarza stanu - $325 \mathrm{mln}$ dol., a sekretarza skarbu - $300 \mathrm{mln}$ dol. Wycena ta nie uwzględnia majątku R. Trumpa, który szacowany jest na 3,7 mld dol. Na krytykę jego wyboru Trump odpowiada, „chcę ludzi, którzy zarobili fortunę, potrafili być przedsiębiorczymi i z pełnym zaufaniem możemy im powierzyć pieniądze publiczne” („Forbes” 2016). Należy wnosić, że sprawowane przez nich funkcje będą traktować nie jako chęć dorobienia się, ale dowartościowania własnej osoby.

${ }^{4}$ Przykładem może być firma Amazon. Według opinii dyrektora ds. pozyskiwania talentów, aby osiągać szybkie tempo wzrostu, należy stawiać na „zatrudnienie najlepszych z najlepszych”. W rekrutacji pracowników szczególną uwagę zwraca się na zdolności analitycznego myślenia, umiejętności kierowania zespołem, kreatywne postawy, dzięki którym możliwe jest ciągłe doskonalenie oferowanych produktów i usług. W Polsce firma poszukuje
} 
rozwoju cywilizacyjnego w poważnym stopniu decydują odpowiednio przygotowane kadry i społeczeństwo. Dla zwiększania efektywności ich działania wymagane są korzystne uwarunkowania, w tym kapitałowo-finansowe, które umożliwią podejmowanie badań podstawowych, laboratoryjnych, wdrożeniowych, a następnie wsparcie w zakresie opatentowania nowych rozwiązań i wprowadzania nowych produktów na rynek.

Należy przyjąć, że w zmieniającym się świecie nasilać się będą procesy integracji, na co wskazują transfery wiedzy, przepływ nowoczesnych rozwiązań technologicznych i technicznych, ludzi, a także kapitału i strumieni finansowych.

Do przyspieszania rozwoju procesów cywilizacyjnych i stwarzania coraz korzystniejszych uwarunkowań dla dalszego rozwoju przedsiębiorczości powinno się zmierzać przez wdrażanie odpowiednich mechanizmów. Mogą tego dokonać tylko odpowiednio przygotowane jednostki o właściwych postawach, które przez wskazywanie odpowiednich wzorców osobowych mogą rozwijać aspiracje i budować racjonalne plany życiowe, zwłaszcza młodzieży. Dla uniknięcia niekorzystnych zachowań ważne jest, aby proces edukacyjny społeczeństwa i talentów oprzeć na odpowiednich zasadach moralnych, pozwalających na wdrażanie zasad etyki w biznesie i życiu społecznym.

Należy się liczyć z tym, że dalszy rozwój przedsiębiorczości może być zakłócony w wyniku nasilających się dysproporcji rozwojowych oraz nieracjonalnych zachowań międzynarodowych i krajowych elit politycznych (Skrzypczak, 2018). Mogą one wpływać na: nasilanie się wyścigu zbrojeń, pojawianie się konfliktów militarnych o różnym zasięgu, wzrost żywiołowych migracji, niezadowolenie społeczne pewnych grup czy wzrost patologii współżycia społecznego i indywidualnego.

Na ten złożony proces wpływają odpowiednio wykształcone postawy i cechy osobowościowe elit władzy i przedsiębiorców (tabela 2). Negatywne cechy przyczyniające się do osłabiania efektywnego zarządzania i gospodarowania znajdują się: egoizm, makiawelizm, zahamowania moralne, narcyzm, poczucie wyższości, psychopatia, sadyzm, status i złośliwość (Użarowska, 2018). Wiele początkowo dobrze rozwijających się podmiotów gospodarczych w układach regionalnych i lokalnych, pomimo korzystnych uwarunkowań, pod wpływem wymienionych negatywnych cech osób zarządzających rozwija się słabiej lub nawet następuje ich recesja.

W następnych latach należy się liczyć z bardzo intensywnie rozwijającą się przedsiębiorczością ludzi o wysokich kwalifikacjach zawodowych i wysokich aspiracjach, którzy będą tworzyć firmy charakteryzujące się dużą innowacyjnością. Dzięki nim pojawiają się nowoczesne produkty, które przyczyniają się do przyspieszania procesów budowania społeczeństwa informacyjnego i gospodarki opartej na wiedzy. Przejawem takiej innowacyjnej przedsiębiorczości są startupy (Skala, 2018). Tworzą je zazwyczaj zespoły projektowe (badawcze), składające się z pasjonatów. Uważają oni, że innowacyjnych pomysłów nie tworzy się z niczego indywidualnie, ale konieczna jest wymiana myśli różnych specjalistów. W kreowaniu pomysłów i ich rozwijaniu w badaniach podstawowych najważniejszym czynnikiem są odpowiednio wykształceni ludzie, a w badaniach eksperymentalnych kluczowe znaczenie mają nakłady finansowe, związane z wysokim ryzykiem. Aby dobry projekt naukowy zmienił się w projekt biznesowy, potrzebny jest

osób o zróżnicowanych umiejętnościach, wykształceniu i doświadczeniu zawodowym, zarówno na stanowiska menadżerskie, jak i poziomu początkowego, a także specjalistów i techników. Firma dociera do odpowiednich kandydatów przez współpracę z polskimi uczelniami oraz przez promocję własnej marki (Yellowlees, 2019). 
Tabela 2. Negatywne cechy osobowości elit władzy i przedsiębiorców

\begin{tabular}{|l|l|}
\hline \multicolumn{1}{|c|}{ Cechy } & \multicolumn{1}{c|}{ Właściwości } \\
\hline Egoizm & $\begin{array}{l}\text { Nadmierne zaabsorbowanie własnymi korzyściami kosztem innych osób } \\
\text { lub społeczności }\end{array}$ \\
\hline Makiawelizm & $\begin{array}{l}\text { Manipulacyjna, bezduszna postawa i przekonanie, że cele uzasadniają } \\
\text { śodki }\end{array}$ \\
\hline $\begin{array}{l}\text { Zahamowanie } \\
\text { moralne }\end{array}$ & $\begin{array}{l}\text { Styl przetwarzania poznawczego, który pozwala zachować się nietycznie } \\
\text { bez odczuwania dyskomfortu }\end{array}$ \\
\hline Narcyzm & $\begin{array}{l}\text { Nadmierna koncentracja na swojej osobie, poczucie wyższości i skrajna } \\
\text { potrzeba uwagi otoczenia }\end{array}$ \\
\hline Poczucie wyższości & $\begin{array}{l}\text { Powtarzające się przekonanie, że ktoś jest lepszy od innych i zasługuje } \\
\text { na lepsze traktowanie }\end{array}$ \\
\hline Psychopatia & Brak empatii i samokontroli w połączeniu z impulsywnym zachowaniem \\
\hline Sadyzm & $\begin{array}{l}\text { Pragnienie wyrządzania szkody psychicznej lub fizycznej dla własnej } \\
\text { przyjemności lub z powodu innych korzyści }\end{array}$ \\
\hline Status & Chęć dalszego podkreślania własnej pozycji społecznej i finansowej \\
\hline Złośliwośćc & $\begin{array}{l}\text { Destrukcyjność i gotowość wyrządzania krzywdy innym, nawet za cenę } \\
\text { szkodzenia samemu sobie }\end{array}$ \\
\hline
\end{tabular}

Źródło: opracowanie na podstawie: Użarowska (2018)

kapitał. Ważnym przesłaniem rozwoju tego typu przedsiębiorczości jest chęć budowania biznesu, który rozwija się innowacyjnie i obejmie rynki światowe. Podstawowym czynnikiem w kształtowaniu rynku jest nowoczesność oferowanych produktów, podnoszących efektywność działalności gospodarczej oraz ich cena. Należy jednak wziąć pod uwagę, że rynki charakteryzują się zróżnicowanym popytem na określone produkty i usługi oraz ich zasięgiem przestrzennym, od układu lokalnego, przez układ regionalny, krajowy do układu międzynarodowego i światowego. Trzeba też wziąć pod uwagę proporcje między endogenicznym a egzogenicznym zagospodarowaniem popytu (Piontek, F., Piontek, B., 2016). Należy jednak pamiętać, że odkrycia naukowe (i związane z nimi nowe produkty) są ważne, ale tylko wtedy, gdy „trafią na umysły do tego przygotowane” (Pascal, 1921). Oznacza to, że aby startupy mogły się rozwijać, konieczne są najczęściej duże firmy, które przez zamówienia będą wdrażać ich innowacyjne produkty ${ }^{5}$.

Każda działalność gospodarcza wymaga jednak korzystnych i stabilnych uwarunkowań polityczno-ustrojowych oraz możliwości określania i przewidywania ich zmian w najbliższych oraz dalszych latach. Natomiast ich brak i związany z tym wzrost ryzyka w znacznym stopniu ograniczają plany rozwijania inwestycji oraz intensyfikowania działalności gospodarczej.

${ }^{5} \mathrm{~W}$ polskich warunkach duże spółki państwowe nie spełniają takich funkcji ze względu ryzyko, ponieważ ewentualne porażki wpłyną negatywnie na dalsze losy decydentów. Inna sytuacja jest w firmach prywatnych, w których ryzykuje się dużo, ale gdy kilka projektów zakończy się sukcesem, pociągnie to za sobą inne przedsięwzięcia. Firma Asseco nowe projekty uzyskuje przez realizację prac wewnętrznych, a także w wyniku współpracy ze startupami oraz korzystając z dofinansowania zewnętrznego. Dzięki powiązaniu z dużą firmą nowe projekty mogą łatwiej trafić na rynek, a ich twórcy mogą liczyć na niezbędne dofinansowanie, przeprowadzenie testów oraz promocję. Bez wsparcia dużej firmy startupy mają nikłą szansę na przebicie się na rynku. Nawet jeżeli opracują dobry produkt, na niewiele się to zda, jeżeli nie potrafią znaleźć na niego odpowiednich kupców (Kucharczyk, Oksińska, 2018). 
Uwagi końcowe

Reasumując, należy przyjąć, że kształtowanie możliwości rozwoju przedsiębiorczości w różnej skali układach przestrzennych jest procesem bardzo złożonym. Dokonuje się ono pod wpływem jakości i potencjału wewnętrznych uwarunkowań: przyrodniczych, ekonomicznych, społecznych, kulturowych i politycznych, a także w wyniku zmieniających się uwarunkowań otoczenia. Czynnikiem dynamicznym określającym kierunek przemian jest nasilenie relacji aktywnych i pasywnych zachodzących między elementami danego układu przestrzennego, relacji kształtujących się w jego otoczeniu, a także relacji zachodzącymi między elementami danego układu a jego otoczeniem. Znaczącą rolę w kształtowaniu układów przestrzennych odgrywają przedstawiciele władzy ustawodawczej, państwowej, samorządowej, instytucji pozarządowych o odpowiednich zasobach intelektualnych, posiadający umiejętności posługiwania się wiedzą, a także występujący na danym obszarze kapitał ludzki i społeczny.

Możliwości dalszego rozwoju przedsiębiorczości w układach przestrzennych bardzo ściśle związane są z wytwarzaniem dotychczasowych produktów, na które aktualnie istnieje rynkowe zapotrzebowanie, a także $z$ wdrażaniem nowych produktów i usług, na które pojawi się określone zapotrzebowanie w przyszłości ${ }^{6}$. Dlatego ważnym problemem jest systematyczna obserwacja chłonności rynku, możliwości jego pogłębiania oraz analiza jego zmian na tle zmieniających się procesów rozwoju.

Należy przyjąć, że podstawą kształtowania przedsiębiorczości i przestrzennych struktur społecznych, gospodarczych i kulturowych są zbieżności interesów podmiotów gospodarczych i społeczeństwa oraz z elementami otoczenia.

Zarysowany proces wyznacza także dalsze kierunki badawcze, które powinny zmierzać do coraz precyzyjniejszego poznania procesu kształtowania przedsiębiorczości w drodze doskonalenia zarówno ujęć teoretycznych, jak i ich weryfikacji w badaniach empirycznych z uwzględnieniem ich możliwości aplikacyjnych.

\section{Literatura}

References

Duszczyk, M. (2018, 2 października). Za dwa lata auta będą latać. Rzeczpospolita - Rzeczpospolita Cyfrowa. Klasik, A., Kuźnik F. (red.). (2018). Rozwój lokalny i regionalny. Teorie i zastosowania. Studia Komitetu Przestrzennego Zagospodarowania Kraju PAN, 184.

Kucharczyk, K. (2018, 10 grudnia). Startupy na celowniku. Rzeczpospolita.

Kucharczyk, K. Oksińska, B. (2019, 7 lutego). Porażka z grafenem to tylko wierzchołek góry lodowej. Rzeczpospolita.

Kuciński, K. (1997). Przestrzenne aspekty przedsiębiorczości. Monografie i Opracowania. Szkoła Główna Handlowa, 430.

Kudełko, J. (2013). Uwarunkowania i kierunki rozwoju województw Polski wschodniej jako regionów słabo rozwiniętych. Studia Komitetu Przestrzennego Zagospodarowania Kraju PAN, 151.

Kudełko, J., (red.). (2007). Uwarunkowania rozwoju rzeszowskiego obszaru metropolitalnego w systemie społeczno-gospodarczym i innowacyjnym województwa podkarpackiego. Prace Komisji Nauk Ekonomicznych, 25, 55-74.

${ }^{6}$ Przykładowo w latach 2017-2018 wartość globalnego rynku grafenu wzrosła z 85 mln dol. do $200 \mathrm{mln}$ dol. i szacuje się, że do $2013 \mathrm{r}$. zwiększy się do 1 mld dol. (Kucharczyk, Oksińska, 2019). Według Polskiego Instytutu Ekonomicznego w latach 2017-2026 wartość polskiego rynku dronów może się zwiększyć z 21,4 mln dol. do 86,6 mln dol., czyli ponad czterokrotnie (Duszczyk, 2018). 
Pascal, B. (1921). Myśli. Przełożył i wstępem opatrzył Tadeusz Żeleński (Boy). Poznań-Warszawa: Księgarnia św. Wojciecha.

Piontek, F., Piontek, B. (2016). Teoria rozwoju. Warszawa: PWE.

Rachwał, T. (2018). Research Issues of the Function of Entrepreneurship in the Socio-Economic Development of Spatial Systems in Polish Economic Geography. Prace Komisji Geografii Przemystu Polskiego Towarzystwa Geograficznego [Studies of the Industrial Geography Commission of the Polish Geographical Society], 32(4), 149-162.

Skala, A. (2018). Startupy. Wyzwanie dla zarządzania i edukacji przedsiębiorczości. Kraków: edu-Libri.

Skrzypczak, W. (2018). Jesteśmy na progu wojny (rozmowa z E. Zemło). Warszawa: Wydawnictwo Czerwone i Czarne.

Szlachta, J. (2018). Terytorializacja jako wyzwanie polityki rozwoju - perspektywa europejska. Studia Komitetu Przestrzennego Zagospodarowania Kraju PAN, 184, 10-19.

Użarowska, M. (2018, 2 października). Czynnik D, czyli ludzki pierwiastek zła. Rzeczpospolita - Nauka.

Yellowlees, G. (2019, 24 stycznia). Rozmowa z dyrektorem ds. pozyskiwania talentów na Europę w Amazon. Rzeczpospolita.

Zioło, Z. (2005). Światowe uwarunkowania rozwoju przedsiębiorczości. Przedsiębiorczość - Edukacja, $1,9-16$.

Zioło, Z. (2006). Rola przedsiębiorczości w podnoszeniu konkurencyjności społeczeństwa i gospodarki . Przedsiębiorczość - Edukacja, 2, 10-17.

Zioło, Z. (2007). Rola przedsiębiorczości w aktywizacji gospodarczej - zarys modelu. Przedsiębiorczość Edukacja, 3, 10-17.

Zioło, Z. (2008). Ekonomiczne i społeczne uwarunkowania rozwoju gospodarki opartej na wiedzy, Przedsiębiorczość - Edukacja, 4, 12-23.

Zioło, Z., Rachwał, T. (red.). (2005). Przedsiębiorczość a współczesne wyzwania cywilizacyjne. Przedsiębiorczość - Edukacja, 1.

Zioło, Z., Rachwał, T. (red.). (2009). Rola przedsiębiorczości w kształtowaniu społeczeństwa informacyjnego. Przedsiębiorczość - Edukacja, 5.

Zioło, Z., Rachwał, T. (red.). (2010). Przedsiębiorczość w warunkach integracji europejskiej. Przedsiębiorczość - Edukacja, 6.

Zioło, Z., Rachwał, T. (red.). (2011). Przedsiębiorczość w warunkach globalizacji. Przedsiębiorczość Edukacja, 7.

Zioło, Z., Rachwał, T. (red.). (2013). Przedsiębiorczość w warunkach kryzysu gospodarczego. Przedsiębiorczość - Edukacja, 9.

Zioło, Z., Rachwał, T. (red.). (2016). Przedsiębiorczość jako czynnik rozwoju układów lokalnych. Przedsiębiorczość - Edukacja, 12.

Zioło, Z., Rachwał, T. (red.). (2017). Uwarunkowania rozwoju przedsiębiorczości. Przedsiębiorczość Edukacja, 13.

Zbigniew Zioło, prof. dr hab., Podkarpacka Szkoła Wyższa im. bł. ks. Władysława Findysza w Jaśle, były wieloletni kierownik Zakładu Przedsiębiorczości i Gospodarki Przestrzennej Instytutu Geografii, Uniwersytetu Pedagogicznego im. Komisji Edukacji Narodowej w Krakowie, Doktor nauk przyrodniczych, dr hab. i profesor nauk ekonomicznych. Jego zainteresowania badawcze to: gospodarka przestrzenna, geografia ekonomiczna, polityka społeczno-gospodarcza, ekonomika i polityka rozwoju regionalnego.

Zbigniew Zioło, professor, Podkarpacka Higher Education School in Jasło, former chair of Department of Entrepreneurship and Spatial Management, Institute of Geography, Pedagogical University of Cracow. He holds a DSc title. He is also a professor of Economics. His research interests include: spatial management, economic geography, socio-economic policies, economics and policies of regional development.

ORCID: 0000-0002-6316-1034 


\section{Adres/Address:}

Uniwersytet Pedagogiczny im. Komisji Edukacji Narodowej w Krakowie

Instytut Geografii

Zakład Przedsiębiorczości i Gospodarki Przestrzennej

ul. Podchorążych 2

30-084 Kraków, Polska

e-mail: zbziolo@onet.eu

Tomasz Rachwal, dr, Uniwersytet Pedagogiczny im. Komisji Edukacji Narodowej w Krakowie, Instytut Geografii, Zakład Przedsiębiorczości i Gospodarki Przestrzennej. Dyrektor Instytutu, kierownik Zakładu, pełni m.in. funkcje: pełnomocnika rektora UP ds. przedsiębiorczości, wiceprzewodniczącego Komisji Geografii Przemysłu Polskiego Towarzystwa Geograficznego, zastępcy redaktora naczelnego czasopism: „Przedsiębiorczość - Edukacja”, „Prace Komisji Geografii Przemysłu Polskiego Towarzystwa Geograficznego” oraz członka redakcji „Entrepreneurial Business and Economics Review”, „Geographia Polonica” oraz „Annales Universitatis Paedagogicae Cracoviensis. Studia Geographica". Jest autorem lub współautorem podręczników szkolnych i akademickich z zakresu geografii ekonomicznej i przedsiębiorczości oraz ekspertem wielu resortów i instytucji w zakresie edukacji ekonomicznej. Jego zainteresowania badawcze skupiają się przede wszystkim na problematyce przemian struktur przestrzennych przemysłu, funkcjonowania różnych branż działalności gospodarczej, restrukturyzacji przedsiębiorstw, roli przedsiębiorczości w rozwoju układów przestrzennych oraz edukacji w zakresie przedsiębiorczości.

Tomasz Rachwal, PhD, Pedagogical University of Cracow, Institute of Geography, Department of Entrepreneurship and Spatial Management. Director of Institute, Head of the Department, Rector's Proxy for Entrepreneurship, a deputy chair of the Industrial Geography Commission of the Polish Geographical Society, A Deputy Editor-in-Chief of the following journals: "Entrepreneurship Education", "Studies of the Industrial Geography Commission of the Polish Geographical Society", and a member of the editorial board of "Entrepreneurial Business and Economics Review", "Geographia Polonica", "Annales Universitatis Paedagogicae Cracoviensis. Studia Geographica". The author or co-author of school and academic textbooks on economic geography and entrepreneurship and expert in many ministries and institutions in the field of economic education. His research interests focus primarily on the issue of change of spatial structures of industry, the functioning of various branches of industrial activity, corporate restructuring and the role of entrepreneurship in the development of spatial systems, as well as entrepreneurship education.

ORCID: 0000-0002-2232-591X

\section{Adres/Address:}

Uniwersytet Pedagogiczny im. Komisji Edukacji Narodowej w Krakowie

Instytut Geografii

Zakład Przedsiębiorczości i Gospodarki Przestrzennej

ul. Podchorążych 2

30-084 Kraków, Polska

e-mail: Tomasz.Rachwal@up.krakow.pl 